\title{
Formation the Model of Criterial Indicators of Resource Potential of Small and Average Business Subjects of Mary El Republic
}

\author{
Svetlata G. Kreneva ${ }^{1}$, Elena N. Halturina ${ }^{1}$, Ilnar M. Nurmuhametov ${ }^{1} \&$ Tatyana B. Bakhtina $^{1}$ \\ ${ }^{1}$ Mari State University, Yoshkar-Ola, Russia \\ Correspondence: Svetlata Kreneva, Mari State University, Republic of Mari El, Russian Federation. Tel: \\ 8-902-737-5940. E-mail: kreneva.sv@yandex.ru
}

\author{
Received: February 21, 2015 Accepted: March 15, 2015 Online Published: April 29, 2015 \\ doi:10.5539/res.v7n8p270 \\ URL: http://dx.doi.org/10.5539/res.v7n8p270
}

\begin{abstract}
.
Participation of Russia in the WTO causes accomplishment of conditions on interaction in world economic system. In this connection there is especially important a studying and an estimation of resource possibilities, development and inclusion of new mechanisms of complex influence on resource potential of various social and economic systems and the country as a whole. Preserving and increasing resource potential of region as one of the main components of national wealth, it is possible for the account research intensity productions in which can be used availability of considerable contingent of qualified personnel, and also decrease in costs.

In this connection the regional policy becomes the key factor in successful the decision of a task of improvement of quality of life of the population on the basis of the accelerated modernisation of economy, activization of investment and innovative activity at active participation of federal subsidising of regions. The requirement for forming of corresponding methodological and methodical base of the regional policy adapted for institutional features and stages of development of the Russian economy and, at the same time, considering world tendencies, and development on its basis of the differentiated approach to the analysis and forecasting of development of each region taking into account its resource potential increases.

The resource potential is the latent possibilities, capabilities, non-realised reserves of a resource which can be shown at change internal and environment. The basic tool of achievement of objects in view of social and economic development of region is provision of interaction of all available resources and possibilities.
\end{abstract}

Keywords: resource potential, social and economic system, the natural indicator, a financial indicator, the labour indicator, the enterprise indicator, integrated indicators, efficiency of small and average business

\section{Introduction}

The easy approach of the foreign enterprises on the regional markets and equalizing by them in the rights with the domestic was raised by requirements to competitiveness of the enterprises, both on external, and in home markets.

A condition of economic development in regions, system of the developed relations in state regulation of a resource policy demand revision of base approaches to management of development of resource potential of region and the country as a whole. Forming of the mechanisms providing their reproduction, quality of their functioning and a state of art in many respects determines an economic situation in each separately taken region (Abramov, 2013).

Transition of developing countries to essentially new technique of social and economic development of a society-Economy of knowledge, innovations, global information systems, economy of intellectual work, the newest technologies and technological venture business, promoted change of accents in arrangement of the resource priorities applied in each situation individually.

Applied methods and mechanisms demand detailed studying of problems of management and reproduction in resource potential and development of new approaches to active use of knowledge, as major resource of development. A main objective at realisation of approaches is necessity for shorter time period not only to reach level of the developed countries, but also to develop strategic directions of the development, allowing to keep stability of economic system, mobility in management of economy in the conditions of input of sanctions concerning the Russian Federation (Bondareva, 2013). 
In a crisis situation in Russia the major place is occupied with questions of reproduction of the resource potential which main component are natural, financial, labour, information and enterprise indicators. In any social and economic system there are a number of restrictions which are a barrier to effective development of resource potential. Therefore it is necessary to generate model criterion indicators of resource potential of subjects of small and average business. Concentration of attention on a studied question speaks level of subjects of small and average business by that the given participants are in a greater degree subject to influence of the crisis phenomena. Forming of conceptual model of development of resource potential assumes to specify the maintenance of the given category, originally (Konoplev, 2014). In the modern theory and practice the resource potential is considered as the integrated category considering features of territory on which the estimation of efficiency of activity of this or that subject is produced. Namely, it is set of various categories of the resources used in activity of subjects of small and average business. It is possible to carry such groups to them as, natural potential, technological potential, human and financial potential, information potential.

Object of research for the purpose of model forming criterion indicators of resource potential are subjects of small and average business of Republic Mary El. So, in 2014 in republic stable growth of industrial production on $13.9 \%$, volume of output of agricultural goods - on $15.8 \%$, turnover of retail trade - on $5.4 \%$, input of apartment houses - on 12.4\% was observed, per capita monetary incomes for January-November, 2014 have grown on $12.1 \%$, a monthly average salary-on $11.9 \%$.

On rates of increase of industrial production Mary El Republic among regions of Privolzhsky federal district for 2014 has occupied the $1^{\text {st }}$ place, the production index has constituted $113.6 \%$.

Considerable growth of industrial production following the results of 2014 is observed in production of oil products (in 2.1 times in comparison with 2013), electric equipment, the electronic and optical equipment-on $28.5 \%$, foodstuff - on $26.5 \%$, production of other nonmetallic mineral products - on $18.3 \%$, vehicles and the equipment-on $12.7 \%$.

In 2014 in republic as growth of volumes of output in agricultural business is observed that on $15.8 \%$ it is more in comparison with 2013

Rates of increase of consumer prices in the consumer market of republic have grown on $5.1 \%$. The Rate of inflation has constituted $111.6 \%$, the mid-annual rise in prices has developed at level of $108.1 \%$.

Results of a monitoring estimation of system effectiveness of business in Mary El Republic have shown that the basic dominant in development of any social and economic system is forming of the sustainable resource potential.

The resource potential assumes forming of group of indicators which form its functional basis, as causes necessity of development of estimate model of any type of social and economic system considering thus development of a resource policy.

The criterial model of resource potential of subjects of social and economic system includes: (Ryzhuk \& Ovchuk, 2012)

-Enterprise potential;

-Scientifically-technological potential;

-Information potential;

-Financial potential;

-Naturally-regional potential;

-Labour potential.

Thus, necessity of forming of resource potential takes on special significance for region with a view of provision of steadily-reproduction mode of development of territory of republic that predetermines development criterial indicators of resource potential of region.

\section{Methods}

Research methods lean against the statistical analysis of indicators of resource potential, and also the analysis of mechanisms of provision of the rational maintenance of indicators of resource potential by means of a method element-by-element category estimations resource potential.

With application of methods of empirical knowledge the essence of resource potential in the conditions of crisis and according to instability of environment is researched and generalised. The category "resource potential" in 
activity of subjects of small and average business is detailed. By means of the intuitive and formalized methods basic reasons of backwardness of resource potential are opened. The supervision method proves importance of labour potential in model forming criterial indicators of resource potential in activity of subjects of small and average business in agricultural business.

\section{Results \& Discussion}

In connection with inducted sanctions concerning the Russian Federation, it is necessary to place priorities on development of agricultural business that in turn dictates necessity to speed up work in the field of management of a man power. It speaks, that the resource potential of Republic of Mary El, is most sensitive concerning change of labour potential.

The basic influence on reproduction of labour potential of agriculture in region is rendered by demographic processes, therefore, first of all, it is necessary to have complete idea about expected population on forthcoming prospect, and then, leaning against a concrete digital material, to develop recommendations about enhancement of process of forming and use of labour potential of agrarian sector of economy (Chagall \& Skopina, 2012).

For forecasting of number of labour potential, it is necessary to lean against the forecast of the basic demographic events - birth rate, death rate and migration. It is natural that they are determined reproductive and recreative by behaviour, social and economic conditions, dynamics of change of these conditions, instability level, level of social optimism, cultural, household, religious traditions of the population and many other factors (Zimovets, 2012).

In republic growth of a standard of living of the population has proceeded. Per capita monetary incomes have increased on $12.1 \%$ and have constituted 15476.4 roubles, the monthly average salary has increased by $11.9 \%$ and has constituted 19909.1 roubles. As the population natural increase was observed, following the results of 2014 the gain has constituted 686 persons, level of the registered unemployment has constituted $0.84 \%$ to a republic gainfully occupied population.

For forecasting is used the method of correlative-regressive analysis. In a general view the sequence of stages of its carrying out is presented as follows:

1) A choice of object of research;

2) Decomposition of generalising indicators on the private;

3) A kit of the indicators included in the scheme;

4) Logic selection of indicators for a correlation analysis;

5) Collection of source information for model construction;

6) A statistical report of indicators;

7) Primary statistical handling of indicators;

8) An estimation of importance of communication between productive criterion and each indicator;

9) A choice of the form of communication;

10) A correlative analysis of regression between steams of indicators;

11) The analysis of indicators of a variation on indicators;

12) A choice of the form of communication;

13) An estimation of importance of communication;

14) Calculation of an error of a representativeness and confidential interests;

15) Practical use of the received results of model.

As a result of the received data and verification of multiplicative model, it is possible to tell about possibility of its use for forecasting of population of social and economic system, as sets of subjects of small and average business on prospect. With a view of increase of efficiency of management by process of reproduction of labour potential of social and economic system the given model will allow at sufficient simplicity of calculations to receive look-ahead values with high degree of reliability.

In actual practice accurately expressed seasonal fluctuations only with increasing or decreasing amplitude to specify difficult enough, therefore for forecasting of number of resident population of Republic of Mary El are used both additive, and multiplicative models. The forecast of number of resident population of Republic of Mary El for short-term prospect by a method of a correlative analysis of regression on the basis of historical data, 
where is performed:

$\mathrm{Y}_{\mathrm{t}}-$ Number of resident population, the people;

$\mathrm{x}_{1}$-Expectational life expectancy, years;

$\mathrm{x}_{2}$-Population with monetary incomes below a living wage, \%;

$\mathrm{x}_{3}$-Number of doctors, the people;

$\mathrm{x}_{4}$-Input of apartment houses, thousand square meters;

$\mathrm{x}_{5}-\mathrm{A}$ rate of unemployment, $\%$;

$\mathrm{x}_{6}$ - Level of employment of the unemployed, $\%$.

Selection of indicators for realisation of a correlative analysis of regression was conducted on the basis of following assumptions:

- Considered set of indicators should reflect results of realisation of a social and economic policy in social and economic system, namely bear social and economic loading;

- The number of the indicators included in model, determines the retrospective period for which should the initial information for the analysis is resulted: $\left(n=4 \cdot x_{1}\right)$,

Where $\mathrm{n}$-number of the periods,

$\mathrm{x}_{1}$ - Number of display signs;

-The increase in quantity of the indicators included in регрессионную model, leads to difficulty of its economic interpretation and reliability decrease.

Preprocessing of the received data which consisted in an estimation of multicollinearity on the basis of construction of a correlation matrix and a step-by-step analysis of regression has allowed to select the following from considered set of indicators: at number of resident population;

$\mathrm{x}_{1}$-Expectation life expectancy, years;

$\mathrm{x}_{3}-$ Number of doctors, the people;

$\mathrm{x}_{4}$-Input of apartment houses, thousand square meters;

And each of these indicators to some extent characterises the social and economic policy in region: expectation life expectancy reflects a condition of a health care and a consequence of a conducted social and economic policy in Mary El Republic, number of doctors also reflects a health care condition, and waters in action of apartment houses - a condition of housing and public utilities and region social policy.

$\mathrm{Y}_{\mathrm{t}}=-124551.24+8627.12 \cdot \mathrm{x}_{1}+123.87 \cdot \mathrm{x}_{2}-60.14 \cdot \mathrm{x}_{3}$

Parameter a $=-124551.24$ - the index point of the readout caused by influence of indicators not considered in model. Regress coefficients at $\mathrm{x}_{1} \mathrm{x}_{2}, \mathrm{x}_{3}$ show change of constant population of Republic of Mary El at increase in display signs of a pas a unit of measure.

Thus, at increase in expectational life expectancy at 1 year there is an increase in number of resident population at 8627 people At increase in number of doctors at 1 people - increase in number of resident population at 123.87 people, and at increase in the same display sign at 100 people - accordingly receive a resident population gain on 12387 people Opposite, at decrease in input of apartment houses on one thousand in sq. $\mathrm{m}$, the gain of number of resident population decreases for 60.14 people

The experimental estimation of parameters of the equation of regress on the basis of Student criterion has shown that settlement values of $t$-criterion more than tabular value of this indicator which in turn for thirteen $(a t=n-m)$ degrees of freedom and a 5 percent significance value constitutes 2.16 . Hence, indicators of multifactorial dynamic model admit significant and in this case is almost improbable that the found values of parameters of the equation are caused only by casual coincidence.

One more indicator of quality of the picked up model traditionally considers coefficient of plural regress. In the case under consideration it is equal 0.75 . It testifies to availability of enough strong communication between the chosen factors and number of resident population. For an estimation of the importance of coefficient of plural correlation we will use equivalent statistics on the basis of Fisher's F-criterion.

$$
F=\frac{n-p-1}{p} \cdot \frac{R_{y x_{1} \ldots x p}}{1-R_{y x_{1} \ldots x p}}
$$


Where:

$\mathrm{n}$-Number of supervision;

$\mathrm{p}-$ Number of factors;

$R_{y x_{1} \ldots x p}$-A cumulative correlation coefficient.

Comparison of settlement value $\mathrm{F}=5.835$ with its table value equal-3.41, at $\mathrm{V}_{1}=3, \mathrm{~V}_{2}=13$ and at a significance value of $5 \%$ testifies to importance of communication, as $\mathrm{F}_{\text {calc }}=5.835>\mathrm{F}_{\text {tabl }}=3.41$. Hence, it is possible to draw a conclusion that the regress equation is statistically significant, that is the share of a variation caused by regress, exceeds a random error and the given equation is really suitable for forecasting.

To estimate degree of cumulative influence of the indicators included in model, it is necessary to use coefficient of determination which is equal 0.574 . It means that $57.4 \%$ of a variation of number of resident population are caused by the indicators which have been selected in model. Thus, the given equation is applicable for accepting of administrative decisions and short-term forecasting of process of reproduction of labour potential.

To realisation of perspective calculations are applied look-ahead by values of display signs on the basis of the average coefficients of growth calculated under the formula of the average geometrical. Then look-ahead values of display signs for 2015 will constitute:

- Expectational life expectancy at a birth: 66.05 years;

- Number of doctors: 2508 people;

- Input of apartment houses: 283.8 thousand square meters.

For 2020 look-ahead values of display signs will constitute:

- Expectation of life expectancy at a birth: 67.9 years;

- Number of doctors: 2514 people;

- Input of apartment houses: 283.9 thousand square meters.

On the basis of the equation of regress and look-ahead values of display signs number of resident population of Republic of Mary El in 2015-2020, table 1 is determined.

Table 1. The forecast of number of resident population Republic Mary El, the people

\begin{tabular}{|c|c|c|c|c|c|}
\hline $\begin{array}{l}\text { The } \\
\text { period }\end{array}$ & look-ahead & $\begin{array}{l}\text { Expectational life } \\
\text { expectancy at a } \\
\text { birth }\end{array}$ & Number of doctors & $\begin{array}{l}\text { Input of apartment } \\
\text { houses }\end{array}$ & $\begin{array}{l}\text { Number } \\
\text { resident } \\
\text { population }\end{array}$ \\
\hline $2015 \mathrm{y}$ & & 66.05 & 2508 & 283.8 & 738868.264 \\
\hline $2020 \mathrm{y}$. & & 67.90 & 2514 & 283.9 & 738311.402 \\
\hline
\end{tabular}

Let's compare the received forecast with given RosStat on the population of Republic of Mary El for 2015 and 2020 , table 2 .

Table 2. The comparative analysis of number of resident population according to a correlative analysis of regression and given RosStat for Republic Mary El, the people

\begin{tabular}{llll}
\hline The look-ahead period & $\begin{array}{l}\text { Given by RosStat } \\
\text { (For January, 1st) }\end{array}$ & $\begin{array}{l}\text { The forecast according to a } \\
\text { korreljatsionno-analysis of } \\
\text { regression }\end{array}$ & $\begin{array}{l}\text { Deviation of } \\
\text { values from } \\
\text { RosStat, \% }\end{array}$ \\
\hline 2015 y. & 703220 & 738868 & $\begin{array}{l}\text { look-ahead } \\
\text { given by }\end{array}$ \\
2020 y. & 700118 & 738311 & 4.82 \\
\hline
\end{tabular}

Thus, look-ahead values of number of resident population Republic Mary El on prospect on a basis correlative-regression analysis deviate from the data of committee of the state statistics of the Russian Federation on size about $5 \%$. Hence, it is possible to recognize the produced calculations authentic with probability of $95 \%$ which is pledged in model. 
A number with markers represents a number of actual indicators which has been approximated and smoothed by a trend line (a polynom of the second degree).

The polynomial trend approximates the fact sheet much better, than the linear offered usual in the literature. Determination coefficient polynomial a trend (0.9932) it is ready above, than linear (0.8942).

We will analysis an average absolute error of each of them:

- Additive model: 0.1147490;

- Multiplicative model: 0.1150981.

Table 3. The comparative characteristic of look-ahead values of number of resident population Republic Mary El according to various techniques and given RosStat

\begin{tabular}{llclll}
\hline Years & $\begin{array}{l}\text { Data and the } \\
\text { forecast } \\
\text { Rosstat }\end{array}$ & $\begin{array}{c}\text { of } \\
\text { multiplicative model }\end{array}$ & $\begin{array}{l}\text { on } \\
\text { The forecast on } \\
\text { additive model }\end{array}$ & $\begin{array}{l}\text { The forecast on model } \\
\text { polynomial a trend }\end{array}$ \\
\hline 2008 & 703220 & 701440 & 701479 & 696021 \\
2010 & 693800 & 691260 & 691354 & 679070 \\
2015 & 676700 & 665906 & 666161 & 627730 \\
2021 & 649900 & 637162 & 637563 & 549222 \\
2026 & 622100 & 614470 & 615000 & 469715 \\
\hline
\end{tabular}

Deviations of result of the forecasts received at use of various models, from the forecast of RosStat, table 4.

Thus, it is obvious that the model polynomial a trend is not suitable for forecasting of number of resident population Republic Mary El even in the long term. For the further forecasting, it is possible to use with identical success both additive, and multiplicative model.

Table 4. Deviations of look-ahead values of number of resident population Republic Mary El according to various techniques from the forecast of RosStat

\begin{tabular}{llll}
\hline Years & $\begin{array}{l}\text { Deviation of the forecast on the } \\
\text { basis of multiplicative model }\end{array}$ & $\begin{array}{l}\text { Deviation of the forecast on the } \\
\text { basis of additive model }\end{array}$ & $\begin{array}{l}\text { Deviation of the forecast on } \\
\text { the } \\
\text { polynomial a trend }\end{array}$ \\
\hline 2008 & 0.253121356 & 0.247589659 & 1.023730838 \\
model
\end{tabular}

The given models well enough describe dynamics of a time number. Value of an average absolute error $(\approx 0.11)$ testifies to split-hair accuracy of model. Confirmation of the made conclusions are also forecasts of number of resident population of Republic Mary El, executed by Rosstat. By results of comparison it is visible that the look-ahead data essentially does not differ.

Thus, the received display models are quite applicable for forecasting of number of resident population of region as a whole, including number, process of reproduction of labour potential of rural business.

For determination of perspective number of agricultural population, table 5, we will use actual values of its share in an aggregate number of the population of Republic Mary El and multiplicative model of forecasting. 
Table 5. The forecast of number of agricultural population Republic Mary El

\begin{tabular}{|c|c|c|c|c|c|c|}
\hline Years & $\begin{array}{l}\text { Number } \\
\text { agricultural } \\
\text { population, } \\
\text { people }\end{array}$ & $\begin{array}{l}\text { of } \\
\text { the }\end{array}$ & $\begin{array}{l}\text { Share of } \\
\text { agricultural } \\
\text { population, \% }\end{array}$ & Years & $\begin{array}{l}\text { Number of agricultural } \\
\text { population, the people }\end{array}$ & $\begin{array}{l}\text { Share of } \\
\text { agricult } \\
\text { ural } \\
\text { populati } \\
\text { on, \% }\end{array}$ \\
\hline 1991 & 286547 & & 37.94 & 2008 & 258531 & 36.86 \\
\hline 1992 & 285038 & & 37.64 & 2009 & 256159 & 36.81 \\
\hline 1993 & 286549 & & 37.79 & 2010 & 254530 & 36.82 \\
\hline 1994 & 285769 & & 37.72 & 2011 & 253185 & 36.90 \\
\hline 1995 & 282504 & & 37.28 & 2012 & 250862 & 36.85 \\
\hline 1996 & 281037 & & 37.16 & 2013 & 249267 & 36.86 \\
\hline 1997 & 279085 & & 37.04 & 2014 & 247949 & 36.94 \\
\hline 1998 & 279547 & & 37.25 & 2015 & 245674 & 36.89 \\
\hline 1999 & 277239 & & 37.09 & 2016 & 244112 & 36.91 \\
\hline 2000 & 274579 & & 36.91 & 2017 & 242822 & 36.99 \\
\hline 2001 & 274254 & & 37.11 & 2018 & 240594 & 36.94 \\
\hline 2002 & 270807 & & 36.96 & 2019 & 239064 & 36.95 \\
\hline 2003 & 267415 & & 36.80 & 2020 & 237801 & 37,03 \\
\hline 2004 & 264813 & & 36.68 & 2021 & 235618 & 36.98 \\
\hline 2005 & 264777 & & 36.94 & 2022 & 234121 & 36.99 \\
\hline 2006 & 262387 & & 36.88 & 2023 & 232883 & 37.07 \\
\hline 2007 & 259964 & & 36.79 & 2024 & 230746 & 37.02 \\
\hline
\end{tabular}

The analysis of the received look-ahead indicators testifies to an adverse demographic situation in region. By 2026 the population of Republic of Mary El will constitute an order 617190 people (an average arithmetic the forecast of Rosstat, additive and multiplicative models) that on 89490 people (13\%) it is less, than in 2015.

Though the agricultural population share in relation to city for this period essentially will not change, by 2020 there will be a reduction number of countrymen on 29218 people or, most likely, slightly more, considering migration in cities and the raised death rate on village.

Therefore at the all-Russian and regional levels urgent measures on management of process of reproduction of labour potential, with allocation of agrarian sector the economy promoting increase of a degree of quality of life should be taken.

To the indicators revealed by results of a correlative analysis of regression essentially influencing labour potential of Republic of Mary El, it is necessary to add professional training system at regional level as in the presence of unemployment there is enough considerable quantity of vacant workplaces both in region as a whole, and in agricultural business (Lemdyaeva, 2012).

The policy directed on population savings should become the basic strategic target of the state and municipal adjustment, allowing to raise value of agricultural work, to lower rural poverty and to provide on this basis economic growth in region.

The basic directions of development of economy of region:

1) Modernisation

- Statistics and accounting reforming;

- A professional training;

- Optimisation of management by economy;

- An effective utilisation of capacities, labour, financial and investment potentials; 
- Active advertising and marketing.

2) Measures of regional support

Creation of regional fund of development;

- The order for improvement of the population and preventive maintenance of diseases;

- Stimulation of creation of new workplaces;

- Investment activity activization;

- Preferential crediting of innovations;

- Granting of credits for habitation;

- Provision of social standards.

3) Re-structuring

- Forming of a market infrastructure;

- Technological re-structuring;

- Indebtedness re-structuring in regional and local budgets;

- Organizational-structural development of economy.

One of directions of adjustment of process of reproduction of labour potential in the rural business focused on optimisation of functioning of households, is realisation of social standardization of the major indicators of social development of region. The great attention should be given to questions of social standardization at development of target regional programs of development as the prevailing number of the rural households which have appeared at level of a poverty line and behind its limits is available.

Construction of system of social standards in region, taking into account its social and economic features, is material-resource possibilities and inquiries of the population, will allow to state more correct estimation of occurring processes.

Social standards urged to provide equal possibilities for all groups of the population in reception of is minimum necessary volume of guarantees in following spheres: payment, labour relations, a retirement income security, social support of the citizens needing protection, formation, public health services, culture, social servicing, housing-and-municipal sphere, provision of favorable environment, sanatorium servicing, a legal aid (Berkowitz, 2014).

Thus, social specifications mention all aspects of reproduction of labour potential of agriculture, as major indicator included in integrated model of an estimation of resource potential of the social and economic subject. Provision of regional minimum vital standards promotes the decision, first of all, demographic problems (decrease in death rate and migration for region limits, birth rate growth). It satirizes application not so much market, how many the state and municipal mechanisms of adjustment.

One of leading spheres of forming of labour potential of corresponding qualification in region is the education system. That the agriculture did not test a lack of highly skilled specialists it is necessary to create such system of a professional training at which in agrarian educational institutions the young men in advance specified with a choice of a professional way will arrive.

The position should be made on those who wants to work in agriculture, to become competitive specialists, the managers who are able and wishing to organise effective agricultural production, to provide comfortable working conditions and rest. Therefore search and support of the talented rural youth should become personnel selection mainstreams in agrarian sector of economy of Republic of Mary El, aspiring to work in agricultural production, its training and special preparation.

Thus, means which now in system of initial vocational training are spent for realisation of general educational programs, should be directed on actually vocational training, and social support should be given to those who needs it.

Realisation of the given approach is a key to the decision of many acute problems, including, for example, such, as increase of a salary of masters of in-service training. In system of forms of social partnership existing by this time in a professional training there is no important link - the search engine of the optimal ways of the decision of personnel problems in each separate industry is not created.

Last years at level of region more and more notable there is a requirement for creation of branch council about 
personnel selection and vocational training for agriculture.

Similar council urged to provide interaction between vocational training organisations, agricultural commodity producers, and also legislative and executive power relevant organs under the decision of problems in sphere of a professional training for agrarian sector of economy.

One of measures of regional adjustment of process of reproduction of labour potential of the necessary qualification for agriculture Republic of Mary El is target contract preparation. For support, provision of equal possibilities at receipt in high schools of talented rural youth target acceptance under contracts with agrarian and industrial complex controls is organised.

To organise the best preparation of the future specialists in training, it is offered to use system of payment for the workers arriving on the enterprises upon termination of educational institutions, allowing within the limits of the limited volume of means of agricultural commodity producers, to stimulate young specialists to development and to promote their fastening on village.

Efficiency from the point of view of additional growth of labour return and fastening at the enterprise of the most perspective employees that above, than more precisely payment reflects the real contribution of everyone, therefore reasonably in due time to produce adjustment of coefficients of an estimation of the work, influencing the sum of the flexible salary, based on level of competitiveness of each worker (Lemdyaeva, 2012).

Competitiveness of the graduate of a higher educational institution is determined by the quality of the got education depending on mode of study, progress (a diploma mean score), a rating of corresponding high school, results production or externship, participation in research work.

Having estimated thus an educational level of finding job graduates of educational institutions, the employer receives representation about base labour potential of candidates on a vacant post and can choose most perspective of young specialists. It is reasonable to add an offered technique with the analysis of personal characteristics of young specialists, using psychological tests.

In activity of subjects of small and average business accepting of effective administrative decisions in the field of management in resource potential can be reduced to following aspects.

To allocate fund of payment of young specialists it is necessary for proportionally established official salary corrected on level of competitiveness.

Researches show that use of the modernised effectiveness ratio of work strengthens salary differentiation, creating thereby advantages in payment for the workers, which competitiveness above average on researched group. It stimulates young specialists on continuation of training and promotes fastening at the enterprise of qualified personnel. It is characteristic that the absolute size of fund of payment thus does not change.

Besides, the legislatively-standard base and a tax policy not to the full meet modern requirements. About what cost efficiency of additional vocational training there can be a speech if variety of lacks here is looked through: the training program is not focused on modern branch professional qualifying standards of specialists; remote training which is cheaper traditional, is used insufficiently; the differentiated financial policy in a choice of programs and modes of study is absent; the requirement of improvement of professional skill of workers of the agricultural enterprises once in five years for the overwhelming majority of professional categories remains traditional while in modern conditions working life of knowledge does not exceed two-three years; means at a choice of terms of training are used irrationally; The policy of priority financing of educational institutions depending on results of their certification is absent.

At the present stage forming of system of additional vocational training should provide high competence of personnel potential of agriculture. It can be promoted by increase of availability of formation, high degree of its personification, integration of formation and consulting services, development of forms of public certification and accreditation of educational institutions, creation of a control system by self-education of commodity producers.

Thus, orientation to the innovative approaches providing its flexibility and adaptability to a condition of an agrarian labour market becomes a strategic direction of development of system of additional vocational training. It is important to improve contractual relations with the enterprises, to develop comprehensive plans of work of the last with corresponding educational institutions on training and personnel development.

Necessary condition of development and system effectiveness of additional vocational training - its orientation to mastering trained the newest methods and technologies of management, ability to adapt them to concrete working conditions. Preparation of administrative shots can be carried without exaggeration to number of 
national priorities of the country. Key value is acquired by reorientation of the Russian production management to the newest concepts and the technologies of management adequate to market changes.

By results of the executed look-ahead calculations on the basis of multiplicative model of a time number, the negative tendency of change of population of Republic of Mary El, including number of a man-power of agriculture is established.

Enhancement of state regulation of reproduction of labour potential of agriculture consists in provision of interaction between legislative and executive power, enterprise entities, vocational training organisations.

The system of reproduction of shots for agrarian sector of economy should be based on continuous multi-level preparation, on principles of wide access to formation, flexibility of curricula and programs.

One of measures of adjustment of process of reproduction of labour potential of agriculture of the necessary qualification at regional level is the organisation of a target contract professional training.

Personnel work at the agricultural enterprises practically is not led. In this connection, it is necessary to conduct a regular estimation of implementation the personnel at the enterprises, used personnel technologies, qualification of employees, efficiency of investments in the personnel, to estimate the organisation of work of personnel service by carrying out of personnel audit.

\section{Acknowledgements}

The author expresses deep gratitude to reviewers for detailed consideration of the manuscript and valuable remarks.

\section{References}

Abramov, I. (2013). The resource potential of Africa: Structure, parameters, the significance for the global economy and internal development. Problems of Modern Economics, 143.

Berkowitz, M. (2014). Economics, Business and Law, development of the concept of enterprise management and its competitiveness on the example of cellular companies.

Bondareva, S. (2013). Business. Education. Law. Bulletin of Volgograd business institute, resource pot entail of personal finance in realization of innovateive investment Policy, 24(3), 189.

Chagall, I., \& Skopina, I. (2012). Man: Resource or potential development in the economy? Co-time control technology (p. 158).

Konoplev, G. (2014). The concept of human resources and strategy of its development. Almanac of modern science and education, 81(2), 86.

Lemdyaeva, L. (2012). The resource potential of the region and approaches to its assessment (on materials of the Sakhalin Region). Regional Economics, 210.

Losev, B. (2012). Methodological position estimation of resource potential gazorasprede-enterprise-inflammatory. Russian Entrepreneurship, 211(13), 100.

Ryzhuk, S. E. (2012). Resource potential of an organization, structure. Bulletin of Altai State Agricultural University, 97(11), 115.

Zabaeva, M. (2012). The Russian Entrepreneurship. Competitiveness Assessment of the resource potential of the building enterprise, 217(19), 67.

Zimovets, O. (2012). The creative economy, increase the resource potential of Research and Production Enterprise.

\section{Copyrights}

Copyright for this article is retained by the author(s), with first publication rights granted to the journal.

This is an open-access article distributed under the terms and conditions of the Creative Commons Attribution license (http://creativecommons.org/licenses/by/3.0/). 